\title{
Evaluation of Groundwater Quality for Industrial Using GIS in Mountainous Region of Isfahan Province, Koh-Payeh, Isfahan, Iran
}

\author{
Mohammad Shayannejad ${ }^{1}$, Zahra Ebrahim-Zadeh ${ }^{1}$, \\ Mohsen Javaheri-Tehrani ${ }^{2}$, Nastaran Zamani ${ }^{1}$, Saeid Eslamian ${ }^{1}$, \\ Maryam Marani-Barzani ${ }^{3}$,Vijay P. Singh ${ }^{4}$, Masoud Kazemi ${ }^{5}$, \\ Kaveh Ostad-Ali-Askari ${ }^{6}$, Zahra Majidifar ${ }^{7}$, Hamid-Reza Shirvani-Dastgerdi ${ }^{6}$ \\ ${ }^{I}$ Department of Water Engineering, Isfahan University of Technology, Isfahan, Iran \\ ${ }^{2}$ Department of Water Engineering and Hydraulic Structures, Faculty of Civil Engineering, Semnan University, \\ Semnan, Iran \\ ${ }^{3}$ Department of Geography, University of Malaya (UM) ,50603 Kuala Lumpur, Malaysia. \\ ${ }^{4}$ Department of Biological and Agricultural Engineering and Zachry Department of Civil Engineering, Texas A \\ and M University, 321 Scoates Hall, 2117 TAMU, College Station, Texas 77843-2117, U.S.A. \\ ${ }^{5}$ Civil Engineering Department, Najafabad Branch, Islamic Azad University, Najafabad, Iran \\ $6^{6 *}$ Department of Civil Engineering, Isfahan (Khorasgan) Branch, Islamic Azad University, Isfahan, Iran \\ ${ }^{7}$ Department of Agronomy and Plant Breeding, Lorestan University, Lorestan, Iran
}

*Corresponding Author: Dr. Kaveh Ostad-Ali-Askari, Department of Civil Engineering, Isfahan (Khorasgan) Branch, Islamic Azad University, Isfahan, Iran. Email: Koa.askari@khuisf.ac.ir

\begin{abstract}
Groundwater quality is gradually deteriorating due to agricultural activities and its evaluation is there for eneeded before use. The aim of this study was to evaluate groundwater quality for use in the foundry industry using water quality data, including PH, EC, TDS, Cl and HCO3, from 26 wells located in Jolgeh and Bon-Rud districts, Iran. Zoning and classification of the area were done, based on groundwater quality, using a GIS software and the existing standards for water use. Results showed that groundwater in the East, North and Southwest of the area was of acceptable quality for use in the foundry industry, but water quality deteriorated from the East to the West of the area. It was found that for foundry industry about 4 percent of area ground water could be used without any limitation, 2 percent with low limitation, 7 percent with moderate limitations, and the rest with high limitation or even unusable. Agricultural activities in the region are having a negative impact on the quality of groundwater.
\end{abstract}

Keywords: Water quality, zoning, foundry industry, $\mathrm{PH}, \mathrm{EC}, \mathrm{TDS}, \mathrm{Cl}, \mathrm{HCO}_{3}$, Jolgehand Bon-Rud

\section{INTRODUCTION}

In recent years, many countries, especially those with dry climate, have been facing water shortages and have therefore resorted to indiscriminate use of groundwater that has led to the deterioration of ground water quality and reduction of groundwater resources. It has been estimated that Iran has 413 billion cubic meters of available water and56 billion cubic meters are extracted from underground aquifers. In 2001 uncontrolled exploitation of about 5.5 billion cubic meters was recorded. Ground water is the main source of water supply in dry and semi-dry areas [1-3] as well as for domestic consumption in many cities of Iran and for agricultural use. Therefore, attention should be paid to the quantity and quality of groundwater resources and their management, especially in dry and semidry areas. Given the scarcity of fresh water resources, crop management and decision-making on land use are of particular importance. Isfahan province, like many other parts of the country, has experienced tworare drought periods over the past 18 years since 1999.Droughts, particularly in the East of Isfahan, have led to drying of about 43 thousand hectares of agricultural land, causing huge damages to farmers who are leaving farmland, and migration from the region to other are asin several cases which is leading to negative social, cultural and economic consequences. In some areas, water quality 
Evaluation of Groundwater Quality for Industrial Using GIS in Mountainous Region of Isfahan Province, Koh-Payeh, Isfahan, Iran

has deteriorated to the extent that groundwater is not usable agriculture. Under these conditions, solutions that can prevent increasing damages to residents are sorely needed. Also careful management of groundwater resources is needed. One of the remedies is land use change that can avert the crisis and help with the subsistence of families. Taking into account the climatic characteristics, topography of the area, the quality and quantity of water resources, area demands, etc., different uses including the construction of industrial workshops can be defined, which are consistent with the existing circumstances and family needs. Because of the water used in industry, water quality in the region should be evaluated and groundwater quality maps of the area should be prepared using GIS Geographical Information System. In the GIS environment, information obtained from various studies can be simultaneously examined. Information on each field forms a layer on the map and the layers can then be combined and analyzed [4-7].

There have been many studies on groundwater quality in Iran. Shabani 2008investigated groundwater quality changes in Arsanjan plain using different geo-statistical methods, including ordinary and simple Kriging, Inverse Distance Weighting method (IDW), radial basis function (RBF), and local and general estimator. His results showed that ordinary and Simple Kriging (SK) methods were superior in the preparation of TDS and $\mathrm{pH}$ maps [8].In order to update information and zoning of groundwater in terms of total hardness and total suspended solids, and determination of the most appropriate areas for the exploitation of groundwater considering potable water standards in Shiraz, samples taken from 137 wells were imported to Arc GIS software and using OK, SK, IDW and RBF interpolation methods and spherical, circular, exponential and Gaussian models, zoning maps of groundwater were developed in another study. Results showed that SK method was the best method for determining suitable areas for ground water exploitation.

In a study using 84 wells in Isfahan it was concluded that Kriging and Co-Kriging methods were not significantly different, but because of a lower RMSE value, Co-Kriging was used in Arc GIS for zoning of groundwater quality [9].Taghi-Zadeh et al.2008 used Co-Kriging to develop groundwater zoning maps in the Ardakan plain, Yazd[10-11]. Imranet al.2014 used data from 36 wells in Southwest of Greece to develop water quality maps of the area by using ordinary Kriging. Results showed that the circular Variogram Method best fitted the EC, $\mathrm{Cl}$ and sodium adsorption ratiodata and the spherical model best fitted the nickel and zinc data [12-13]. Yaoet al. 2014investigated an aquifer surface using 8 methods e. g. ordinary, simple, and universal Kriging, etc. and indicated that the Kriging methods yielded more accurate results than other interpolation methods [13-15]. In another study, Ordinary Kriging (OK) and (IK) index were used to find the spatial and temporal variability and the possibility of increasing groundwater salinity. It was concluded that the Kriging method was a useful technique for observation, evaluation and management of groundwater resources [16-19].

As mentioned before, water crisis, especially in the East of Isfahan including Jolgeh and Bon-Rud areas, has caused a lot of problems. For example, the average groundwater surface in the area has dropped from 16. 41 meters in 2002 to 17.29 meters in 2009, and the average groundwater EC has increased from 9.192 in 1995to $11.453 \mathrm{dS} / \mathrm{m}$ in 2012 with an approximate increase in salinity of $25 \%$.In this area there are large amounts of low-quality water. Under these conditions, the revival of low-water-consuming industries can help sustain local economy as well as industries for which water quality does not matter much, such as industries in which water is used as a coolant in keeping with regulations.

In this study, considering different geostatistical methods and existing standards of water consumption in industry, the foundry industry was selected for the Jolgeh and Bon-Rud districts in the Southeast of Isfahan province. Therefore, the aim of this study was to investigate the quality and spatial changes in groundwater characteristics, including EC, PH, TDS, and CL, and develop maps and perform feasibility study for application in the foundry industry using the Arc GIS software [20-24].

\section{MATERIALS AND METHODS}

\subsection{Study Area}

The study was conducted on the Jolgeh and Bon-Rud districts located in the southeast part of Isfahan province. Jolgeh district with a population of 19,822 is limited to the Kuhpayehfromnorth, to the BonRud from east, to the central part of Isfahan from west and to the Jarqavieh from south. It includes Rudasht and EmamzadehAbdol Azizvillages. The area of the district is 1824.6 square kilometers and 
Evaluation of Groundwater Quality for Industrial Using GIS in Mountainous Region of Isfahan Province, Koh-Payeh, Isfahan, Iran

is located between the eastern lengths of $52^{\circ} 03^{\prime} 58^{\prime \prime}$ and $53^{\circ} 03^{\prime} 27^{\prime \prime}$ and northern latitudes of $32^{\circ} 09^{\prime}$ $37 "$ and $32^{\circ} 41^{\prime} 31^{\prime \prime}$ with an altitude of 1,540 meter above sea level.

Bon-Rud district with a population of 26,299 is limited to the Kuhpayeh from north, to Yazd province from east and to the Jolgeh from south and west and includes Eastern Rudasht and Gavkhuni villages. The area of the district is 1721.4 square kilometers and is located between the eastern lengths of $52^{\circ} 24^{\prime} 48^{\prime \prime}$ and53 $3^{\circ} 03^{\prime} 33^{\prime \prime}$ and northern latitudes of $32^{\circ} 17^{\prime} 09^{\prime \prime}$ and $32^{\circ} 37 ' 50^{\prime \prime}$ with an altitude of 1,477 meter above sea level. The location of Jolgeh and Bon-Rud districts is shown on the map in Figure 1 [25-32].

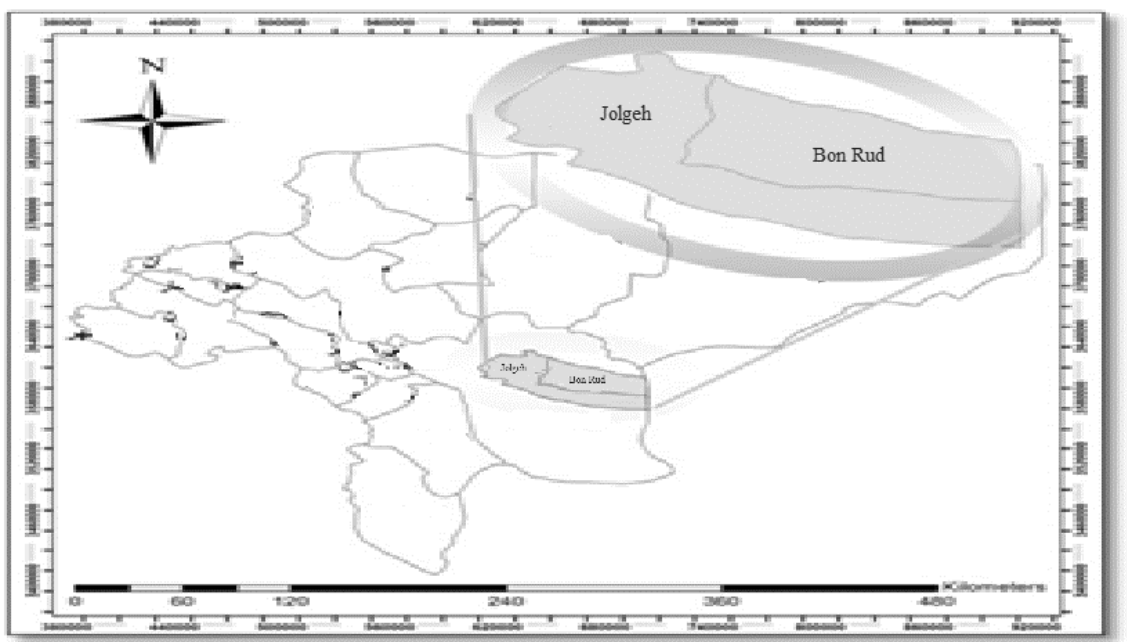

Figure1. Location of the Jolgeh and Bon-Rud districts on the map of Isfahan province

\subsection{Methodology}

Data was collected by the Isfahan Regional Water Company in 2012 and consists of UTM coordinates of wells and PH, EC hydraulic conductivity, TDS (Total Dissolved Solids), CL and HCO3valuesfor each well. To map groundwater quality changes in the area, the GIS software was used. The GIS software can produce, process, analyze and manage geographic information spatial information. It is a computer software to manage and analyze spatial information with the ability to collect, store, analyze and display geographic spatial information. The ultimate goal of a GIS is to support decision-making, based on spatial information and its basic function is to obtain information from a combination of different layers of data obtained with different methods and with different perspectives [33-39].

Data was entered into the GIS and the zoning of study area was initiated. The normality of the data was examined by using the histogram. Then, zoning of the groundwater quality was done using three interpolation methods of IDW, Radial Basis Function and ordinary Kriging methods, as in the study of Zahedifar, Mousavi and Rajabi who used Ordinary Kriging for the zoning of groundwater quality [40-52].Then, based on the lowest Root Mean Square Error RMSE and Mean Error ME values, the best interpolation was selected. However, results showed that in some of the interpolations, concentration ranges exceeded the minimum and maximum values. Therefore, an accurate estimate of the area was not achieved, since the above-mentioned methods were used for areas with normal data. However, Jahanshahi, Moghadam and Dehvary used Kriging in a study and obtained accurate results, because the data in the study area was normal [53-59]. Finally, groundwater quality interpolation was done again using the Topo to Raster interpolation method and EC, PH, TDS, Cl and HCO3 changes maps were developed separately. The maps were then classified and evaluated using Reclassify and Weighted sum functions in terms of water quality using Table 1 standards which was an estimation of the American standards for the industrial units' construction as well as European, Malaysian and Korean Standards [60-78], to be used in the foundry industry.

Table1. Standards of water quality for use in the foundry industry

\begin{tabular}{|c|c|c|c|}
\hline Parameter & No limitation & Moderate to low limitation & High limitation \\
\hline EC $(\mathrm{dS} / \mathrm{m})$ & $<3 / 5$ & $3.5-8$ & $>8$ \\
\hline $\mathrm{TDS}(\mathrm{mg} / \mathrm{L})$ & $<1500$ & $1500-3500$ & $>3500$ \\
\hline $\mathrm{Na}^{2}(\mathrm{meq} / \mathrm{L})$ & $<5$ & $>5$ & - \\
\hline
\end{tabular}


Evaluation of Groundwater Quality for Industrial Using GIS in Mountainous Region of Isfahan Province, Koh-Payeh, Isfahan, Iran

\begin{tabular}{|c|c|c|c|}
\hline \hline $\mathrm{Na}^{2}(\mathrm{mg} / \mathrm{L})$ & $<115$ & $>115$ & - \\
\hline $\mathrm{CL}^{2}(\mathrm{meq} / \mathrm{L})$ & $<4.75$ & $>4.75$ & - \\
\hline $\mathrm{CL}^{2}(\mathrm{mg} / \mathrm{L})$ & $<285.5$ & $>285.5$ & - \\
\hline $\mathrm{HCO}_{3}(\mathrm{meq} / \mathrm{L})$ & $<1.5$ & $1.8-5.5$ & $>8.5$ \\
\hline $\mathrm{HCO}_{3}(\mathrm{mg} / \mathrm{L})$ & $<400$ & $400-620$ & $>620$ \\
\hline $\mathrm{PH}$ & \multicolumn{2}{|c|}{} \\
\hline
\end{tabular}

\section{RESULTS}

Zoning results of groundwater quality for the foundry industry:

Figure 2 shows the EC changes in the study area. In addition, Table 2 shows the area classification based on the foundry industry standards.

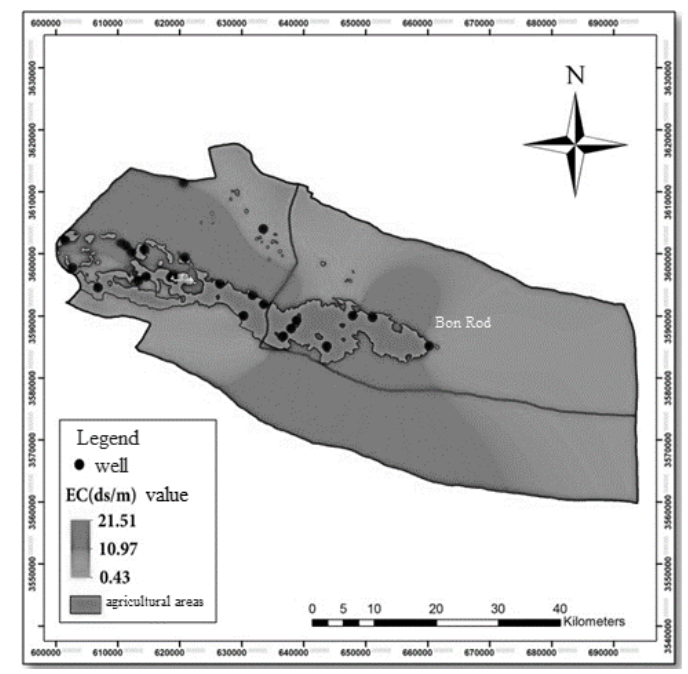

Figure2. EC changes of the Jolgeh and Bon-Rud groundwater

Table2. Area corresponding to each EC class

\begin{tabular}{|c|c|c|c|}
\hline range & limitation & Area & Area percent \\
\hline$<3.5$ & No limitation & 31526.5 & 10.2 \\
\hline $3.8-5$ & Moderate to low limitation & 87912.214 & 28.4 \\
\hline$>8$ & High limitation & 190200 & 61.4 \\
\hline
\end{tabular}

As can be seen from Figure 2, the EC ranged from 0.43 to $21.51 \mathrm{dS} / \mathrm{m}$ with the highest value in the south and northwest of the area.

According to Table 2, most parts of the area had an EC over $8 \mathrm{dS} / \mathrm{m}$ and the average EC was 7.15 $\mathrm{dS} / \mathrm{m}$.

Figure 3 and Table 3show $\mathrm{Cl}$ changes and classification of the area based on the foundry industry standards.

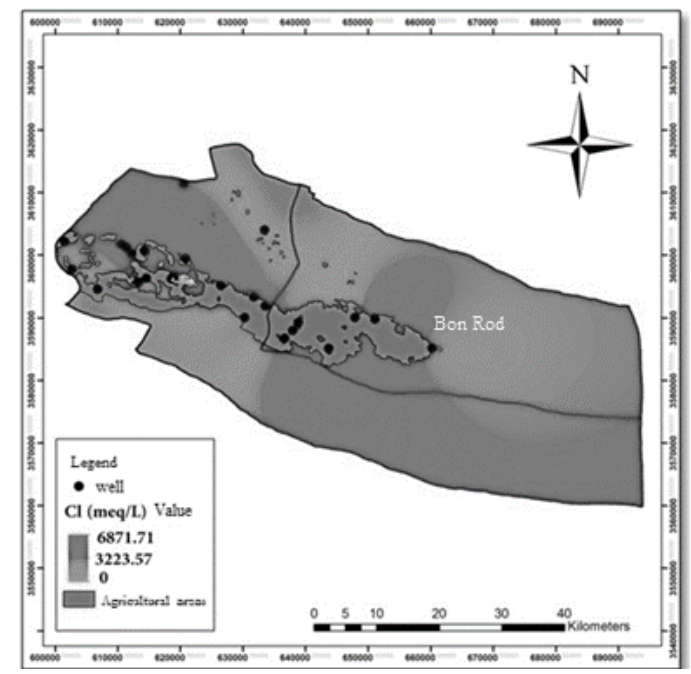

Figure3. Changes of groundwater Cl in Jolgeh and Bon-Rud districts 
Evaluation of Groundwater Quality for Industrial Using GIS in Mountainous Region of Isfahan Province, Koh-Payeh, Isfahan, Iran

Table3. Area of each class $C L$

\begin{tabular}{|c|c|c|c|}
\hline range & limitations & area & Area percent \\
\hline$<285.5$ & No limitation & 225.2 & 0.07 \\
\hline$>285.5$ & Moderate to low limitation & 309400 & 99.95 \\
\hline
\end{tabular}

According to Fig. 3, $\mathrm{Cl}$ changes from 0 to $6871.71 \mathrm{meq} / \mathrm{L}$ and the highest value was observed in the center and northwest of the area.

According to Table 3, most parts of the area had aCl concentration over $285.5 \mathrm{meq} / \mathrm{L}$ and the average $\mathrm{Cl}$ concentration was about $290 \mathrm{meq} / \mathrm{L}$.

Figure 4 and Table 4show Na changes and classification of the area based on the foundry industry standards.

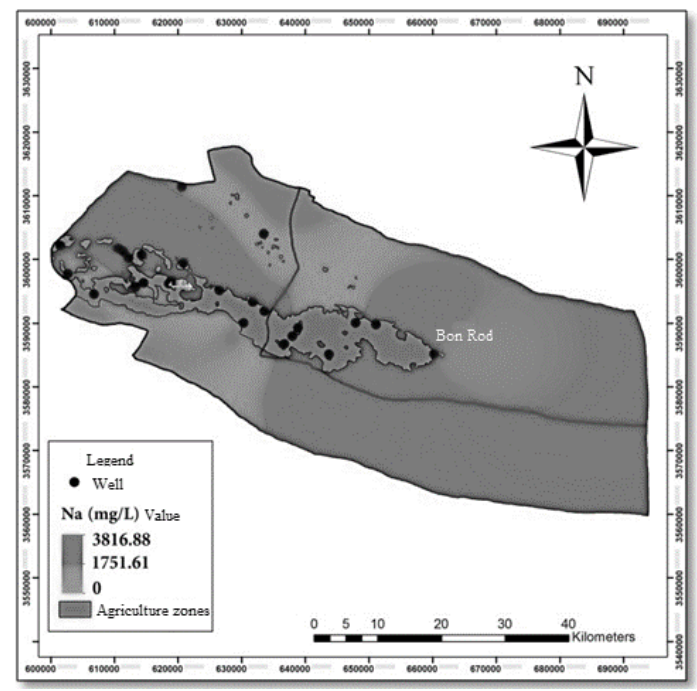

Figure4. Changes of groundwater Na in Jolgeh and Bon-Rud districts

Table4. Area of each Na class

\begin{tabular}{|c|c|c|c|}
\hline range & Limitations & area & Area percent \\
\hline$<115$ & No limitation & 5897 & 1.9 \\
\hline$>115$ & Moderate to low limitation & 303700 & 98.1 \\
\hline
\end{tabular}

According to Fig. 4, Na changed from 0 to $3816.88 \mathrm{mg} / \mathrm{L}$ and the highest value was observed in the center and west of the area.

According to Table 4, most parts of the area had a Na concentration over115 mg/L and the average $\mathrm{Na}$ concentration was $124 \mathrm{mg} / \mathrm{L}$.

Figure 5 and Table 5show HCO3changes and classification of the area based on the foundry industry standards.

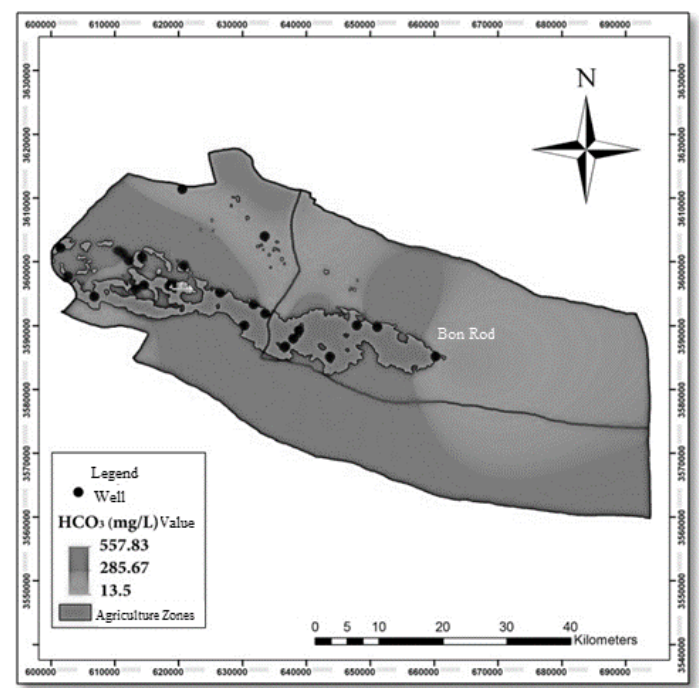

Figure5. Changes of groundwater HCO3 in Jolgeh and Bon-Rud districts 
Evaluation of Groundwater Quality for Industrial Using GIS in Mountainous Region of Isfahan Province, Koh-Payeh, Isfahan, Iran

Table5. Area of each $\mathrm{HCO} 3$ class

\begin{tabular}{|c|c|c|c|}
\hline range & Limitations & area & Area percent \\
\hline$<400$ & No limitation & 250800 & 81.01 \\
\hline $400-620$ & Moderate to low limitation & 58789 & 18.9 \\
\hline
\end{tabular}

According to Fig. 5, HCO3 changed from 13.5 to $557.83 \mathrm{mg} / \mathrm{L}$ and the highest value was observed in the center, south and west of the area.

According to Table 5, most parts of the area had anHCO3 concentration less than $400 \mathrm{mg} / \mathrm{L}$ and the average $\mathrm{HCO} 3$ concentration was $340 \mathrm{mg} / \mathrm{L}$.

Figure 6 and Table 6show PH changes and classification of the area based on the foundry industry standards.

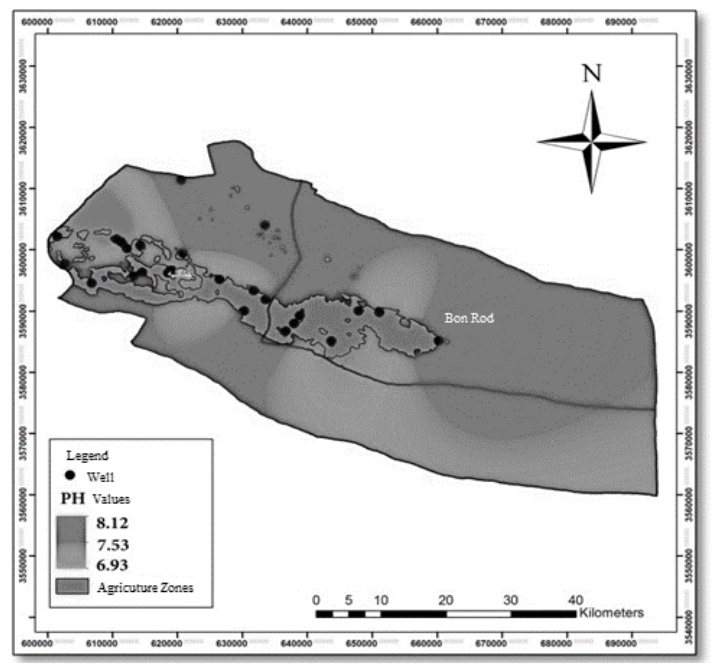

Figure6. Changes of groundwater PH in Jolgeh and Bon-Rud districts

Table6. Area of each PH class

\begin{tabular}{|c|c|c|}
\hline Range PH & Area(ha) & Area percent(\%) \\
\hline $6.5-8.4$ & 309634.9 & 100 \\
\hline
\end{tabular}

According to Fig. 6, PH changes from 6.9 to $7.93 \mathrm{mg} / \mathrm{L}$ and the highest value was observed in the north and east of the area.

According to Table 6, whole groundwater of the area can be used in the foundry industry with no limitation.

Figure 7 and Table 7show TDS changes and classification of the area based on the foundry industry standards.

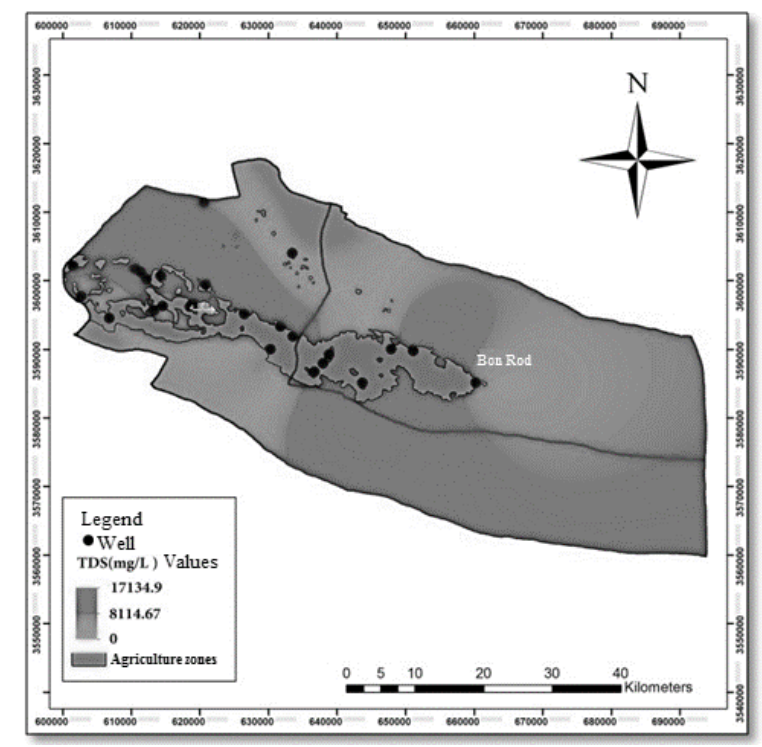

Figure7. Changes of groundwater TDS in Jolgeh and Bon Rud districts 
Evaluation of Groundwater Quality for Industrial Using GIS in Mountainous Region of Isfahan Province, Koh-Payeh, Isfahan, Iran

Table7. Area of each TDS class

\begin{tabular}{|c|c|c|c|}
\hline range & limitations & area & Area percent \\
\hline$<1500$ & No limitation & 11871.9 & 8.3 \\
\hline $1500-3500$ & Moderate to low limitation & 21263 & 6.9 \\
\hline$>3500$ & High limitation & 276500 & 89.3 \\
\hline
\end{tabular}

According to Fig. 7, TDS changes from 0to $17134.0 \mathrm{mg} / \mathrm{L}$ and the highest value was observed in the center and west of the area.

According to Table 7,most parts of the area had a TDS concentration over3500 mg/L and the average TDS concentration was $3872.5 \mathrm{mg} / \mathrm{L}$

Figures 8 and 9 show the classification of the area based on all mentioned components' standards. In Figs. 8 and 9, the same and different factors of the impact can be observed, respectively.

In Fig. 9, the impact factor of HCO3 and TDS was considered as 3 because of the possible clogging of pipes, and the impact factor of $\mathrm{Cl}$ was considered as 2 because of the possible corrosion of pipes, and the remaining impact factors were considered as 1 . As can be seen because of different classification bases of the two figures, different limitations were observed, but in both cases the area was divided into 5 classes based on the software standards. Table 8shows the are as corresponding to different classes in Fig. 8.

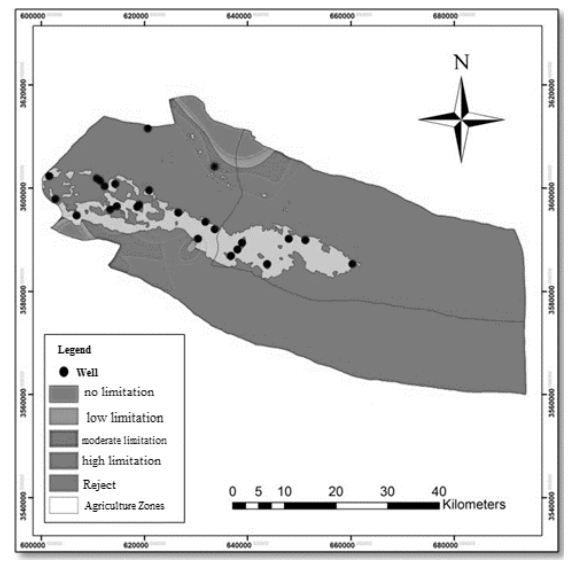

Figure8. Classification of the area considering standard ranges of all the components with the same impact factors

Table8. Area corresponding to different classes in Figure 8

\begin{tabular}{|c|c|c|c|}
\hline row & Limitation & area & Area percent \\
\hline 1 & No limitation & 8084.51 & 2.61 \\
\hline 2 & Low limitation & 3750.31 & 4.21 \\
\hline 3 & Moderate limitation & 13574.21 & 5.39 \\
\hline 4 & High limitation & 17589.08 & 8.68 \\
\hline 5 & Rejected & 266553.87 & 86.11 \\
\hline
\end{tabular}

Table 9 shows the area corresponding to different classes in Figure 9.

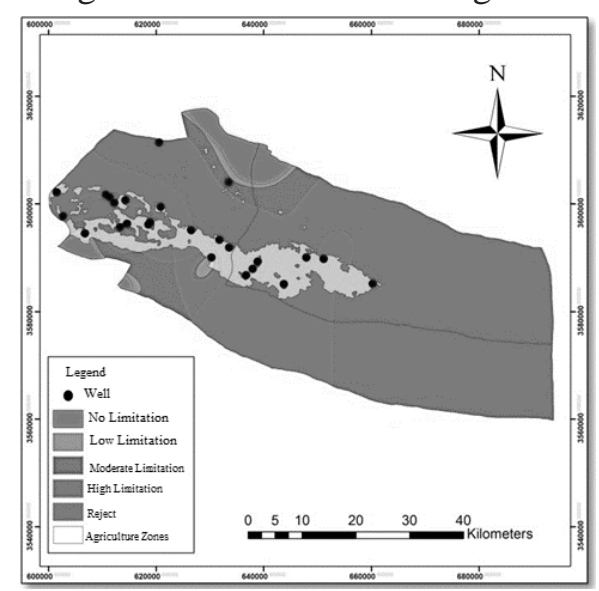

Figure9. Classification of the area considering standard ranges of all the components with different impact factors 
Evaluation of Groundwater Quality for Industrial Using GIS in Mountainous Region of Isfahan Province, Koh-Payeh, Isfahan, Iran

Table9. Area corresponding to different classes in Figure 9

\begin{tabular}{|c|c|c|c|}
\hline row & limitation & area & Area percent \\
\hline 1 & No limitation & 12010.42 & 3.88 \\
\hline 2 & Low limitation & 4046.38 & 1.31 \\
\hline 3 & Moderate limitation & 21809.07 & 7.05 \\
\hline 4 & High limitation & 205415.7 & 66.36 \\
\hline 5 & Rejected & 66270.30 & 21.41 \\
\hline
\end{tabular}

According to Table 8 , most parts of the area cannot be used for the foundry industry and generally, 8.21 percent of the area has no limitation to low limitation for use in the foundry industry. However, according to Table 9most parts of the area have high limitation for use in the foundry industry andgenerally, 12.24 percent of the area has no limitation to moderate limitation for use in the foundry industry.

\section{CONClusions}

Due to corrosion and clogging potential of pipes, a higher impact factor should be considered for the $\mathrm{Cl}, \mathrm{HCO} 3$ and TDS parameters. Therefore, according to Table 9 only 4 percent of the total area groundwater can be used in the foundry industry with no limitation, which is too small. It is recommended to treat low limitation groundwater of other areas using water treatment devices so that can be used for industrial use.

The very small percentage of the area groundwater with no limitation for use in industry suggests that no agricultural activities should be undertaken in the area, because of 26 wells only 3 wells have an EC less than $3 \mathrm{dS}$. m. This is against what Chitsazan, Botvandi and Majediindicated in their research on zoning groundwater quality of Ghal'e Khaje plain, Khuzestan that the majority of the plain has a good to average groundwater quality for agricultural purposes, and just a small amount of the area groundwater quality is not suitable.

Not only the area groundwater is not suitable for agriculture purposes, but also just a small amount thereof is suitable for industrial use. Therefore, management practices must be considered to prevent further contamination of the area groundwater in the future as well as removing the current contamination to an acceptable level in order to render suitable for use in industry.

\section{REFERENCES}

[1] Botvandi Gholampour, F., Chitsazan, M. and Majeid, H., 2013, Groundwater quality Zoning IN Khaje Ghal'e, Khouzestan in terms of agricultural and potable uses using the quality standards and GIS software, the $5^{\text {th }}$ conference of Iran Water Resources Management, Tehran, Iran,Water Resources Association, Beheshti University.

[2] Jahanshahi, A. Rouhi Moghadam, E. and DehvariE., 2013, Evaluation of groundwater quality parameters using GIS and geostatistics,Case Study: Shahr-e-Babak aquifer, Journal of soil and water. Volume 24, No. 2: 183-197.

[3] Zahedifar, M., Mousavi, E.,and Rajabi, M., 2013, Zoning of Chemical groundwater properties ofFasa plain using geostatistical methods, Journal of Soil and Water, Agricultural Science and Technology, Volume 27, No. 4: 812-822.

[4] Shabani, M., 2008, Determination of the best geostatistical methodin mapping groundwater PH and TDS, Case Study: ArsanjanPlain. Journal of water engineering. 1: 47-58.

[5] Mahdavi, R., Abedi Koupaie, J., Rezaei, M. and Abdolhoseini, M., 2004, "Positioning suitable sites for artificial recharge of groundwater resources using RS and GIS. $2{ }^{\text {nd }}$ National Student Conference ofSoil and Water Resources. Shiraz University.

[6] Arslan, H. 2012. Spatial and temporal mapping of groundwater salinity using ordinary kriging and indicator kriging: The case of Bafra Plain, Turkey. Agricultural water management 113, 5763.

[7] Chitsazan, M., Rahmani, Gh. and Neyamadpour, A. 2013. Groundwater level simulation using neural network: A case study from Aghili plain, urban area of Gotvand, south- west Iran. J. Geope, 3: 35-46. 
Evaluation of Groundwater Quality for Industrial Using GIS in Mountainous Region of Isfahan Province, Koh-Payeh, Isfahan, Iran

[8] El-Sayed Ewis Omran, Ahmed Ghallab, Salman Selmy and Abd-Alla Gad. 2014. Evaluation and Mapping Water Wells Suitability for Irrigation Using GIS in Darb El-Arbaein, South Western Desert, Egypt. International Journal of Water Resources and Arid Environments 3(1): 63-76.

[9] Nasiri. Abouzar. And Alipur. Hamid.2014. Estimation of Spatial Distribution of Groundwater Quality Parameters using Geostatistical Methods - A Case Study of ISFAHAN- IRAN. Journal of Engineering and Technology Science, IJETS. 2(2):159-173.

[10] Robert, E., Michaelis \& LeRoy, L. and Wyman.1964.Standards Reference Materials: Preparation of NBS white cast Iron spectrochemical standards, National Bureau of standards Miscellaneous Publication 260-1. Library of congresscatalog card number: 64- 60045.

[11] Taghizadeh Mehrjardi, R., ZareianJahromi, M., Mahmodi, Sh., and Heidari. 2008. Spatial Distribution of Groundwater Quality with Geostatistics, Case Study: Yazd-Ardakan Plain. World Applied Sciences Journal 4 (1): 09-17.

[12] Yao, L., Huo, Z., Feng, Sh., Mao, X., Kang, Sh., Chen, J., Xu, J. and Steenhuis, T.S., 2014. Evaluation of spatial interpolation methods for groundwater level in an arid inland oasis, northwest China. Environmental Earth Science. 71:1911-1924.

[13] Shayannejad, M., Akbari, N., Ostad-Ali-Askari, K. 2015, Study of modifications of the river physical specifications on muskingum coefficients, through employment of genetic algorithm. International Journal of Development Research, 5(3), 3782-3785.

[14] Ostad-Ali-Askari, K., Shayannejad, M. 2015, Study of sensitivity of Autumnal wheat to under irrigation in Shahrekord, Shahrekord City, Iran. International Journal of Agriculture and Crop Sciences, 8 (4), 602-605.

[15] Ostad-Ali-Askari, K., Shayannejad, M. 2015, The Reviews of Einstein's Equation of Logarithmic Distribution Platform and the Process of Changes in the Speed Range of the Karkheh River, Khuzestan province, Iran. International Journal of Development Research, 5(3), 3786-3790.

[16] Ostad-Ali-Askari, K., Shayannejad, M., Ghorbanizadee-Kharazi, H. 2015, Assessment of artificial neural network performance and exponential regression in prediction of effective rainfall, International Journal of Development Research, 5(3),3791-3794.

[17] Shayannejad, M. Akbari, N. and Ostad-Ali-Askari, K. 2015, Determination of the nonlinear Muskingum model coefficients using genetic algorithm and numerical solution of the continuity. Int. J. of Science: Basic and Applied Research, 21(1),1-14.

[18] Ostad-Ali-Askari, K., Shayannejad, M. 2015, The Study of Mixture Design for Foam Bitumen and the Polymeric and Oil Materials Function in Loose Soils Consolidation. Journal of Civil Engineering Research, 5(2), 39-44. DOI: 10.5923/j.jce.20150502.04

[19] Sayedipour, M., Ostad-Ali-Askari, K., Shayannejad, M. 2015, Recovery of Run off of the Sewage Refinery, a Factor for Balancing the Isfahan-Borkhar Plain Water Table in Drought Crisis Situation in Isfahan Province-Iran. American Journal of Environmental Engineering, 5(2): 43-46. DOI: 10.5923/j.ajee.20150502.02

[20] Ostad-Ali-Askari, K., Shayannejad, M. 2015, Developing an Optimal Design Model of Furrow Irrigation Based on the Minimum Cost and Maximum Irrigation Efficiency. International Bulletin of Water Resources \& Development, 3(2), 18-23.

[21] Ostad-Ali-Askari, K., Shayannejad, M. 2015, Presenting a Mathematical Model for Estimating the Deep Percolation Due to Irrigation. International Journal of Hydraulic Engineering, 4(1), 17 21. DOI: 10.5923/j.ijhe.20150401.03.

[22] Ostad-Ali-Askari, K., Shayannejad, M. 2015, Usage of rockfill dams in the HEC-RAS software for the purpose of controlling floods. American Journal of Fluid Dynamics, 5(1), 23-29. DOI: 10.5923/j.ajfd.20150501.03.

[23] Ostad-Ali- Askari, K., Shayannejad, M. 2015, The effect of heterogeneity due to inappropriate tillage on water advance and recession in furrow irrigation. Journal of Agricultural Science, 7(6), 127-136.

[24] Shayannejad, M., Ostad-Ali-Askari, K. 2015, Effects of magnetized municipal effluent on some chemical properties of soil in furrow irrigation. International Journal of Agriculture and Crop Sciences, 8(3), 482-489. 
Evaluation of Groundwater Quality for Industrial Using GIS in Mountainous Region of Isfahan Province, Koh-Payeh, Isfahan, Iran

[25] Ostad-Ali-Askari, K., Shayannejad, M. 2015, Optimal design of pressurized irrigation laterals installed on sloping land. International Journal of Agriculture and Crop Sciences, ISSN 2227670X. 8(5), 792-797.

[26] Ostad-Ali-Askari K, Shayannejad M, Eslamian S, Navab-Pour B. 2016, Comparison of solution of Saint-Venant equations by characteristics and finite difference methods for unsteady flow analyzing in open channel. International Journal of Hydrology Science and Technology, 6(3), 918.

[27] Eskandari S, Hoodaji M, Tahmourespour A, Abdollahi A, Mohammadian-Baghi T, Eslamian S, Ostad-Ali-Askari K. 2017, Bioremediation of Polycyclic Aromatic Hydrocarbons by Bacillus Licheniformis ATHE9 and Bacillus Mojavensis ATHE13 as Newly Strains Isolated from OilContaminated Soil. Journal of Geography, Environment and Earth Science International, 11(2): $1-11$.

[28] Ostad-Ali-Askari K, Eslamian S, et al. 2017, Development of a new method for determination of infiltration coefficients in furrow irrigation with natural non-uniformity of slope. Sustain. Water Resour. Manag., 3(2): 163-169.

[29] Shafaei-Bejestan M, Eslamian S, Marani-Barzani M, P. Singh V, Kazemi M, Ostad-Ali-Askari K. 2017, Assessment of Drainage Slope on the Manning Coarseness Coefficient in Mountain Area. International Journal of Constructive Research in Civil Engineering, IJCRCE, 3(1): 33-40.

[30] Bahmanpour H, Awhadi S, Enjili J, Eslamian S, Ostad-Ali-Askari K. 2017, Optimizing Absorbent Bentonite and Evaluation of Contaminants Removal from Petrochemical Industries Wastewater. International Journal of Constructive Research in Civil Engineering, IJCRCE, 3(2): 34-42.

[31] Shayannejad M, Eslamian S, Gandomkar A, Marani-Barzani M, Amoushahi-Khouzani M, Majidifar Z, Rajaei-Rizi F, Kazemi M, P. Singh V, Dehghan SH, Shirvani-Dastgerdi H.R, Norouzi H, Ostad-Ali-Askari K. 2017, A Proper Way to Install Trapezoidal Flumes for Measurements in Furrow Irrigation Systems. International Journal of Research Studies in Agricultural Sciences, IJRSAS, 3(7): 1-5.

[32] Dehghan Sh, Kamaneh S.A.A., Eslamian S, Gandomkar A, Marani-Barzani M, AmoushahiKhouzani M, Singh V.P., Ostad-Ali-Askari K. 2017, Changes in Temperature and Precipitation with the Analysis of Geomorphic Basin Chaos in Shiraz, Iran. International Journal of Constructive Research in Civil Engineering, IJCRCE, 3(2): 50-57.

[33] Ostad-Ali-Askari K, Shayannejad M. 2016, Flood Routing in Rivers by Muskingum's Method With New Adjusted Coefficients. International Water Technology Journal, IWTJ, 6(3): 189-194.

[34] Ostad-Ali-Askari K, Shayannejad M, Ghorbanizadeh-Kharazi H. 2017, Artificial Neural Network for Modeling Nitrate Pollution of Groundwater in Marginal Area of Zayandeh-rood River, Isfahan, Iran. KSCE Journal of Civil Engineering, 21(1):134-140.Korean Society of Civil Engineers. DOI 10.1007/s12205-016-0572-8.

[35] Shayannejad M, Ostad-Ali-Askari K, Ramesh A, Singh V.P., Eslamian S. 2017, Wastewater and Magnetized Wastewater Effects on Soil Erosion in Furrow Irrigation. International Journal of Research Studies in Agricultural Sciences (IJRSAS), 3(8): 1-14. http://dx.doi.org/10.20431/ 2454-6224.0308001

[36] Eslamian, S. S., 2013, Groundwater and Surface Water Interaction (GSWI): 3: Unconvenntional Groundwater, International Journal of Water, Special Issue Volume, Inder sciences, Vol. 7, No. $1 / 2,1-141$.

[37] Eslamian, S. S., 2011, Groundwater and Surface Water Interaction (GSWI): 2. Case Studies, International Journal of Water, Special Issue Volume, Indersciences, Vol. 6, No. 1, 1-136.

[38] Eslamian, S. S., 2009, Groundwater and Surface Water Interaction (GSWI): 1. Quality, International Journal of Water, Special Issue Volume, Indersciences, Vol. 5, No. 2, 81-204.

[39] Shahid, S., Alamgir, M., Wang, X.-J., Eslamian, S., 2017, Climate Change Impacts on and Adaptation to Groundwater, Ch. 6 in Handbook of Drought and Water Scarcity, Vol. 2: Environmental Impacts and Analysis of Drought and Water Scarcity, Ed. by Eslamian S. and Eslamian F., Francis and Taylor, CRC Press, USA, 107-124. 
Evaluation of Groundwater Quality for Industrial Using GIS in Mountainous Region of Isfahan Province, Koh-Payeh, Isfahan, Iran

[40] Gaaloul, N., Eslamian, S., and Laignel, B., 2017, Contamination of Groundwater in Arid and Semiarid Lands, Ch. 16 in Handbook of Drought and Water Scarcity, Vol. 2: Environmental Impacts and Analysis of Drought and Water Scarcity, Ed. by Eslamian S. and Eslamian F., Francis and Taylor, CRC Press, USA, 291-314.

[41] Kruse, E., Eslamian, S., 2017, Groundwater Management in Drought Conditions, Ch. 11 in Handbook of Drought and Water Scarcity, Vol. 3: Management of Drought and Water Scarcity, Ed. by Eslamian S. and Eslamian F., Francis and Taylor, CRC Press, USA, 275-282.

[42] Qian, Q., and Eslamian, S., 2015, Groundwater Recharge and Unconventional Water: Design and Management Criteria, Urban Water Reuse Handbook, Ch. 61, Ed. By Eslamian, S., Taylor and Francis, CRC Group, 809-816.

[43] Eslamian, S., Okhravi, S. and F. Eslamian, 2014, Groundwater-Surface Water Interactions, in Handbook of Engineering Hydrology, Ch. 13, Vol. 1: Fundamentals and Applications, Ed. By Eslamian, S., Francis and Taylor, CRC Group, USA, 251-279.

[44] Abdolvandi, A. F., Eslamian, S. S., Heidarpour, M., Babazadeh, H., Parsamehr, A., 2013, Simultaneous Simulation of both Surface and Groundwater Resources Using System Dynamics Approach (Case Study: Taleghan Dam), Advances in Environmental Biology, Vol. 7, No. 4, 562-570.

[45] Saatsaz, M., Azmin Sulaiman, W. N., Eslamian, S., Javadi, S., 2013, Development of a coupled flow and solute transport modelling for Astaneh-Kouchesfahan groundwater resources, North of Iran, International Journal of Water, Vol. 7, No.1/2, 80 - 103.

[46] Saatsaz, M., Azmin-Sulaiman, W. N., Eslamian, S., Mohammadi, K., 2013, Hydrogeochemistry and groundwater quality assessment of Astaneh-Kouchesfahan Plain, Northern Iran, International Journal of Water, Vol. 7, No. 1/2, $44-65$.

[47] Eslamian, S., Amiri, M. J., Abedi-Koupai, J. and S. Shaeri-Karimi, 2013, Reclamation of unconventional water using nano zero-valent iron particles: an application for groundwater, International Journal of Water, Vol. 7, No. 1/2, 1-13.

[48] Ghazavi, R., A. B. Vali and S. Eslamian, 2012, Impact of Flood Spreading on Groundwater Level Variation and Groundwater Quality in an Arid Environment, Water Resource Management, Vol. 26, No. 6, 1651-1663.

[49] Eslamian, S. S., Shaeri Karimi S. and F. Eslamian, 2011, A country case study comparison on Groundwater and Surface Water Interaction, International Journal of Water, Vol. 6, Nos. 1/2, 117-136.

[50] Saatsaz, M., Sulaiman, W.N.A. and S. S. Eslamian, 2011, GIS DRASTIC model for groundwater vulnerability estimation of Astaneh-Kouchesfahan Plain, Northern Iran, International Journalof Water, Vol. 6, No. 1/2, 1-14.

[51] Saatsaz, M., Chitsazan, M., Eslamian, S. S. and W.N.A. Sulaiman, 2011, The application of groundwater modelling to simulate the behaviour of groundwater resources in the Ramhormooz Aquifer, Iran, International Journal of Water, Vol. 6, Nos. 1/2, 29-42.

[52] Saatsaz, M., Chitsazan, M., Eslamian, S. S. and W.N.A. Sulaiman, 2011, The application of groundwater modelling to simulate the behaviour of groundwater resources in the Ramhormooz Aquifer, Iran, International Journal of Water, Vol. 6, Nos. 1/2, 29-42.

[53] Eslamian, S. S. and N. Lavaei, 2009, Modelling Nitrate Pollution of Groundwater using Artificial Neural Network and Genetic Algorithm in an Arid Zone, International Journal of Water, Special Issue on Groundwater and Surface Water Interaction (GSWI), Vol. 5, No. 2, 194203.

[54] Eslamian, S. S. and B. Nekoueineghad, 2009, A Review on Interaction of Groundwater and Surface Water, International Journal of Water, Special Issue on Groundwater and Surface Water Interaction (GSWI), Vol. 5, No. 2, 82-99.

[55] Abdolvandi, A.F., Parsamehr, D., Babazadeh, H., Eslamian, S. and Hosseinipour, E.Z., 2014, Conjunctive Use of Surface and Groundwater Resources Using System Dynamics Approach (Case Study: Namroud Dam), World Environmental \& Water Resources Congress, USA. 
Evaluation of Groundwater Quality for Industrial Using GIS in Mountainous Region of Isfahan Province, Koh-Payeh, Isfahan, Iran

[56] Bateni M., Eslamian, S. S., Mousavi, S. F. and E. Z. Hosseinipour, 2012, Application of a Localization Scheme in Estimating Groundwater Level using Deterministic Ensemble Kalman Filter, EWRI/ASCE 10th Symposium on Groundwater Hydrology, Quality and Management, USA.

[57] Mirabbasi, R. and S. S. Eslamian, 2010, Delineation of Groundwater Quality Concerning Applicability of Pressure Irrigation System in Sirjan Watershed, Iran, International Conference on Management of Soil and Groundwater Salinization in Arid Regions, Sultan Qaboos University, Muscat, Oman.

[58] Malekian, R., Abedi-Koupai, J. and S. S. Eslamian, 2010, An Effective Method to Reduce Groundwater Pollution in Farmlands, The 1st Annual Conference- Ibb 2010, Environmental Science and Technology, Republic of Yemen.

[59] Eslamian, S. S., M. J. Amiri and W. Balderer, 2009, A Review on Thermal Spring in Iran, Groundwater, Thermal and Mineral Water in Areas of Arid Conditions: Consequences for the Current Situation of Climate Change and the Increasing Population of Egypt, IAH-CMTW Workshop, Cairo, Egypt.

[60] Eslamian, S. S., Tabatabaei H., Abedi Koupaei, J. and R. Nazari, 2003, A Mathematical and Management Model of Groundwater with Emphasis on Artificial Recharge for Damaneh Plain, Isfahan Province of Iran, The Second International Conference on Salt Water Intrusion and Coastal Aquifers, Merida, Mexico.

[61] Eslamian, S. S. and M. Afyuni, 2003, Investigating Nitrate Contamination in the Groundwater of Isfahan Plain, Iran, 5th International Congress of Turkish Society of Toxicology, Antalya, Turkey.

[62] Ayati, H., and S. Eslamian, 2008, Modeling of North Mahyar Plain Groundwater Using MODFLOW Model, Nama.

[63] Eslamian, S. S. and A. Ghodarzi, 2007, Evaluation of flood spreading system and artificial recharge of Bagh-sorkh aquifer in Shahreza on groundwater quality and quantity, Soil and Water Journal, Vol. 21, No. 1, 145-153.

[64] Tabatabaei, S. H., Tavasoli M., Eslamian S. S. and G. Ahmadzade, 2006, Investigating groundwater pollution of Esfahan city and its evaluation with emphasize on drinking water, Scientific Journal of Agriculture, Vol. 29, No. 2., 79-92.

[65] Kiaheirati, J., Eslamian, S. S. and H. Khademi,2002, Evaluating performance of flood spreading for ground water table artificial recharge, Iranian Natural Resources Journal, Vol. 55, No. 2., 159-171.

[66] The application of Artificial Neural Network and ArcGIS in groundwater rable simulation of Mahyar plain. Isfahan Province, The Second National Congress on Irrigation and Drainage, August 23-25, Isfahan, Iran.

[67] Behzadi-Nasab, M., Eslamian S. S. and Y., 2002, Influence of water pumping on groundwater surface level in west region of Dez irrigation network, 1st Student Conference on Soil and Water Resources, Urumia University, Iran.

[68] Eslamian S, Amoushahi-Khouzani M, Marani-Barzani M, Ostad-Ali-Askari K. 2017, A Simple Method for Land Grading Computations and its Comparison with Genetic Algorithm (GA) Method. International Journal of Research Studies in Agricultural Sciences (IJRSAS), 3(8): 2638.

[69] Eslamian S, Ostad-Ali-Askari K, Soltani M. 2017, Climate Variability: Integration of Renewable Energy into Present and Future Energy Systems in Designing Residential Buildings. International journal of Rural Development, Environment and Health Research(IJREH), 1(2): 18-30.

[70] Shayannejad M, Ostad-Ali-Askari K, Eslamian S, et al. 2017, Flow Hydraulic Investigation of the Wastewater on the Soil and Magnetic Field Effects in This Field. International Journal of Constructive Research in Civil Engineering (IJCRCE), 3(3): 1-15.

[71] Ostad-Ali-Askari K, Eslamian S, Shayannejad M, et al. Groundwater Hydrodynamic. Horoufchin Publisher. First Edition, 2016. ISBN: 978-600-7419-53-3. Isfahan, Iran. 
Evaluation of Groundwater Quality for Industrial Using GIS in Mountainous Region of Isfahan Province, Koh-Payeh, Isfahan, Iran

[72] Eslamian S, Mirabbasi-Najafabadi R, Ostad-Ali-Askari K. Advance Engineering Statistics (Simulation and Modeling of Uncertainty and Sensitivity Analysis). Kankash Publisher. First Edition, 2017. ISBN: 978-600-136-359-7. Isfahan, Iran.

[73] Ostad-Ali-Askari K, Shayannejad M, Eslamian S, et al., Environmental Hydraulics of Open Channel Flows. Kankash Publisher. First Edition, 2015. ISBN: 978-600-136-303-0.

[74] Ostad-Ali-Askari K, Shayannejad M, Golabchian M. Numerical methods in groundwater. Kankash publisher. First edition, 2015. ISBN: 978-600-136-276-7. Isfahan, Iran.

[75] Shayannejad M, Ostad-Ali-Askari K. Optimization and its application in water resources management. Kankash publisher. First edition, 2015. ISBN: 978-600-136-248-4. Isfahan, Iran.

[76] Ostad-Ali-Askari K. Groundwater. Horoufchin publisher, First Edition, 2015. ISBN: 978-6007419-33-5. Isfahan, Iran.

[77] Shayannejad M, Ostad-Ali-Askari K. Modeling of solute movement in groundwater. Kankash publisher. First edition, 2015. ISBN: 978-600-136-256-9. Isfahan, Iran.

[78] Ostad-Ali-Askari K, Shayannejad M, Ghorbanizadee-Kharazi H. 2017, Artificial Neural Network for Modeling Nitrate Pollution of Groundwater in Marginal Area of Zayandeh-rood River, Isfahan, Iran. KSCE Journal of Civil Engineering, 21(1):134-140. Korean Society of Civil Engineers. DOI 10.1007/s12205-016-0572-8.

\section{AUTHORS' BIOGRAPHY}

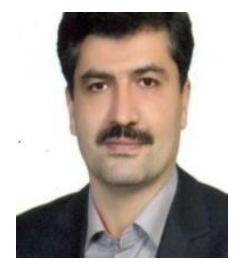

Dr. Mohammad Shayannejad, Is an associate professor in the Department of Water Engineering, College of Agriculture, Isfahan University of Technology, Iran. He was awarded a $\mathrm{PhD}$ in irrigation and drainage engineering from the University of Tarbiat Modarres, Tehran, Iran. He has more than 17 years of research, teaching, and technical consulting experiences in irrigation and drainage engineering.

Zahra Ebrahim-Zadeh, Department of Water Engineering, Isfahan University of Technology, Isfahan, Iran

Mohsen Javaheri-Tehrani, Department of Water Engineering and Hydraulic Structures, Faculty of Civil Engineering, Semnan University, Semnan, Iran.

NastaranZamani, Department of Water Engineering, Isfahan University of Technology, Isfahan, Iran

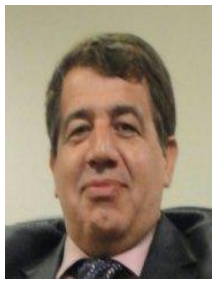

Professor Saeid Eslamian, is a full professor of water system engineering in the Department of Water Engineering at Isfahan University of Technology, Iran, where he has been since 1995. He received his PhD from Civil and Environmental Engineering School, University of New South Wales, Sydney, Australia, under the supervision of Professor David Pilgrim. His research focuses mainly on water resources planning, management, and sustainability and statistical and environmental hydrology in a changing climate. Formerly, he was a visiting professor at Princeton University, New Jersey, and University of ETH Zurich, Switzerland. On the research side, he started a research partnership in 2014 with McGill University, Montreal, Quebec, Canada. He has contributed to more than 770 publications in journals, books, or as technical reports. He is the founder and chief editor of both the International Journal of Hydrology Science and Technology (Scopus, Inderscience) and the Journal of Flood Engineering. Professor Eslamian is also associate editor of the Journal of Hydrology (Elsevier) and Ecohydrology and Hydrobiology (Elsevier). He has authored more than 250 book chapters and books. Recently, Professor Eslamian published eight handbooks with Taylor \& Francis Group (CRC Press) as chief editor: a three-volume Handbook of Engineering Hydrology (2014), Urban Water Reuse Handbook (2015), a three-volume Handbook of Drought and Water Scarcity (2017), and Underground Aqueducts Handbook (2016).

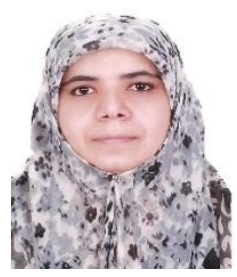

Maryam Marani-Barzani, Department of Geography, University of Malaya (UM),50603 Kuala Lumpur, Malaysia. Member of Suggestion Committee in Ministerial of Education in Iran (2002-2007). Member of Research on Heat Sink Capability of Inland Water Resources for Thermal Power Plants in Peninsular Malaysiaproject (TNBR)(2014-2015). Member of Board Trustees at Consultant Engineering Company (Sharsazan Zendeh Rood) in Iran.(2015-peresent). 
Evaluation of Groundwater Quality for Industrial Using GIS in Mountainous Region of Isfahan Province, Koh-Payeh, Isfahan, Iran

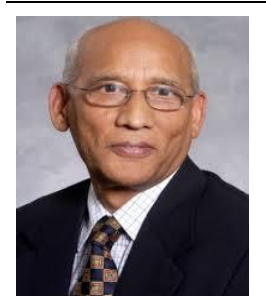

Professor Vijay P. Singh, Ph.D., D.Sc., D. Eng. (Hon.), Ph.D. (Hon.), D.Sc. (Hon.), P.E., P.H., Hon. D. WRE, Academician (GFA), Distinguished Professor, Regents Professor, Caroline and William N. Lehrer Distinguished Chair in Water Engineering

President, FARA, President, G.B.S. Board, Editor-in-Chief, Water Science and Technology Library Book series, Editor, Global Water Resources Book Series, Editor-in-Chief, Journal of Ground Water Research, Editor-in-Chief, Open Agriculture, Editor, Journal of Agricultural Research, Department of Biological and Agricultural Engineering \&Zachry Department of Civil Engineering, Texas A and M University.

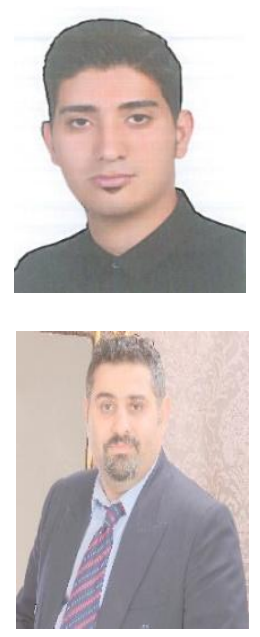

Masoud Kazemi, M.Sc. student of Civil Engineering, Civil Engineering Department, Najafabad Branch, Islamic Azad University, Iran.He has been an expert in various projects of Civil Engineering and technical software such as AutoCAD and MATLAB ${ }^{\circledR}$ programming

Dr. KavehOstad-Ali-Askari, is a $\mathrm{PhD}$ of civil engineering, Department of Water Resources Engineering, Faculty of Civil Engineering. His topics of interest include Groundwater Hydrology, Irrigation and Drainage Engineering, Sustainable Development and Environmental Assessment, Climate and Integrated and Sustainable Water Resource Management, Water System Engineering, Water Resources Planning, Artificial Neural Network, and Genetic Algorithm. He has contributed to more than 125 publications in Journals, Books and Technical Reports. He collaborates as Editorial Board Membership in more than 45 Journals and as reviewers in more than 30 Journals. Currently, he is a Faculty Member of the Department of Civil Engineering, Isfahan (Khorasgan) Branch, Islamic Azad University, Iran. He is Editor-in-Chief of International journal of Rural Development, Environment and Health Research (IJREH) and Associate Editorial Board Membership of International Journal of Environmental Sciences \& Natural Resources (IJESNR) and Civil Engineering Research Journal (CERJ), Juniper Publishers. He was a Visiting Assistant Professor at Canadian University Dubai (CUD), Dubai, UAE, and American University in Dubai (AUD), UAE. On the research side, he started a research partnership in May 2017 with Concordia University in Montreal, Quebec, Canada.

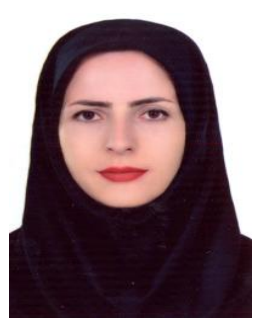

Zahra Majidifar, She has a Bachelor in Agronomy and Plant Breading from Lorestan University, Iran. Her interested topics are GIS AND Agronomy.

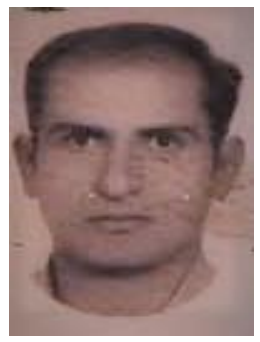

Hamid-Reza Shirvani-Dastgerdi, M.Sc. of Civil Engineering, Department of Civil Engineering, Isfahan (Khorasgan) Branch, Islamic Azad University, Isfahan, Iran.

Citation: Dr. Kaveh Ostad-Ali-Askari et al. (2017) Evaluation of Groundwater Quality for Industrial Using GIS in Mountainous Region of Isfahan Province, Koh-Payeh, Isfahan, Iran, International Journal of Constructive Research in Civil Engineering, 3(3), pp.23-37.

Copyright: () 2017 Dr. Kaveh Ostad-Ali-Askari, et al. This is an open-access article distributed under the terms of the Creative Commons Attribution License, which permits unrestricted use, distribution, and reproduction in any medium, provided the original author and source are credited. 